\title{
Migration, remittance and development in origin countries: evidence from Nigeria
}

\author{
John S. Afaha \\ Department of Economics, University of Ibadan \\ johnafaha@yahoo.com
}

\begin{abstract}
Migration (international or local migration) of individuals/workers is viewed as a channel through which workers' remittances have become a major source of income for developing countries; resources are repatriated from the source country to service foreign nationals or home economy while it creates an internal brain drain between local migrants and likely an increased outmigration of workers/individuals. However, little is still known about their impact on the economic development in the origin countries. This paper analyses whether, and to what extent, these downsides of international migration of workers affects origin countries. Consequently, using a household survey-based and secondary sources dataset our results show that remittances in Nigeria are positively and significantly viable in their contribution to economic growth (proxy by gross domestic product) in some Sub-Saharan African countries and have reduced poverty to some extent.
\end{abstract}

Keywords: Remittances, economic growth, migration, development, Nigeria.

\section{Introduction}

For decades the migration debate has focused on the impact of immigration on destination countries. Very recently, however, attention has increasingly turned to the situation in the countries of origin, developing countries in particular, with a focus on the interplay between migration and development. Three compensatory mechanisms offer migrants' countries of origin a possibility for avoiding the permanent loss of knowledge and qualified labour due to migration (i.e. the brain drain) as well as a means of escaping from the poverty trap. Firstly, circular migration - the practice of migrating back and forth between the countries of origin and destination can create, at a minimum, the potential for increased knowledge exchange, if not gain (brain gain). Secondly, diaspora communities can serve as a conduit for developing trade connections, increasing the transfer of capital and exchanging technology. Finally, the steady growth of remittances from migrants to families back home can significantly help reduce poverty in recipient communities.

Nigeria plays a key role in African migrations. As Africa's demographic giant, Nigeria has become increasingly involved in international migration to Europe, the Gulf countries and South Africa. Yet Nigeria is also a source and destination country of migration within West Africa (Adepoju 2004). Considering the key role Nigeria plays in African migration systems, its role as destination, transit and source country, and considering the fact that it is confronted with both the negative and positive dimensions of migration, improved systematic insight in the views and interests of Nigerian state and non-state stakeholders is essential in designing more effective migration and development.

On the other hand, remittances have become significant private financial resources for households in countries of origin of migration, although they cannot be considered as a substitute for foreign direct investment (FDI), official development assistance (ODA), debt relief or other public sources of finance development. There has been a 15-fold increase in remittances to developing countries since 1988, with remittances increasing from $\$ 20$ billion to $\$ 328$ billion in 2007. This makes it important to continue to analyse the potential of migrants' remittances to contribute to development. Though there is a growing literature on the impact of remittances on development, very few studies have empirically estimated the impact of remittances on development in general, especially in origin countries. To fill this gap in the literature, this study undertakes an impact analysis of remittances.

The gap between migrants from developing countries to developed countries and to other developing countries has reduced over time. In 2005, the migrant stock from developing countries to developed countries was around 53 per cent, while to other developing countries it was around 47 per cent. Studies have pointed out that most migration, and especially the migration of the poor, takes place between developing countries. In terms of number of emigrants, developing countries take the lead and account for around 95 per cent of total emigrants. The remittance flows are accordingly much higher to developing countries. In 2008, the top 10 remittances-receiving countries were developing countries. In 2007, the total remittances to developing countries through official sources was estimated at 
$\$ 328$ billion; it is likely that billions more are transferred through unofficial sources (World Bank, 2009). For many developing countries, the remittance flow has grown not only in size but also in importance in terms of their share of GDP. In many developing countries, more than 20 per cent of GDP is contributed by remittances. In this context, it becomes important to estimate the impact of remittances on poverty levels in developing countries. Using the panel data for 77 developing countries for the period 1980-2008, the study estimates the impact of remittances on poverty headcount ratios.

The goal of this study is the critical examination of remittances as a link between the migration and development debates. It focuses on the migration patterns in Nigeria with emphasis on the Lagos Survey $(2010)$ and then extends the study to other countries. Secondly, it takes into account the procedures and motives for such transfers as well as an overview of current trends and figures. It then addresses the importance of remittances with respect to poverty reduction, income distribution, spending habits, education, health, investment and growth as well as the national balance of payments in developing countries. Finally, the conclusion addresses the question of whether migration and the resulting flow of funds could evolve into a springboard for development in these countries.

To gain this insight, this study aims at identifying key issues, obstacles and potential synergies in maximising the positive effects of migration and remittances on national development and minimising the negative effects from the perspective of the Nigerian state, key civil society actors and their organisations. This goal has been achieved through the study of available documentation (articles, reports, policy documents, undocumented notes) and series of interviews and institutions ranging from Nigerian ministries and agencies, local NGOs, European and African foreign embassies to several multilateral organisations such as the IOM, WORLDBANK, ILO and ECOWAS.

The rest of the paper is organised as follows: section two provides a brief background and review of literature. Section three discusses the data sources and econometric technique and section four focuses on the conclusion and policy implications of the study.

\section{Background and literature review}

\subsection{Nigerian migration}

\subsubsection{Basic facts on Nigeria}

With an estimated over 160 million inhabitants, Nigeria is the most populous country in Africa. It became a British protectorate in 189I (although initially this mainly comprised the coastal areas), and became independent in 1960. Nigeria has more than 250 different ethnic and linguistic groups, with the major divide running between the predominantly Muslim north and the predominantly Christian south. The largest ethnic groups are the HausaFulani (north), Yoruba (southwest) and lbo (southeast). Nigeria is a federal republic, with the 36 states enjoying considerable political and juridical autonomy. Lagos is the country's economic capital and, with an estimated population of between 10 to 15.5 million people, Africa's second largest city. Centrally located Abuja was proclaimed the nation's capital in 1976, located in the federal capital territory state, although the actual move from Lagos to Abuja took place in 1991. Other major cities are Kano in the north, Ibadan in the southwest and Port Harcourt in the southeast, the latter a major site of oil refineries. From 1966 until 1999, Nigeria was ruled by several military dictators, except for a short period of civilian administration between 1979 and 1983. Besides the several coups, the country's history has been characterised by a series of minor and major violent interethnic conflicts, the bloodiest of which was the Nigerian Civil War (1967-1970) between Nigeria and the breakaway republic of Biafra.. Democracy was formally restored in 1999, when current president Olusegun Obasanjo was elected. Nigeria is an influential member of the African Union and the Commonwealth of Nations. It is also a member of and hosts the secretariat of the Economic Community of West African States (ECOWAS), which was founded in 1975.

Despite the country's oil wealth, many Nigerians suffer from extreme poverty. Between 1980 and 2000 , per capita income fell. In 2004, GNI per capita stood at 400 US\$, lower than the 510 US\$ average for all low-income countries. In the same year, life expectancy at birth was 45 years against a 58 years average for low income countries. Approximately 90 million Nigerians are believed to live in absolute poverty, on less than one dollar a day. 


\section{Map 1. Nigerian states}
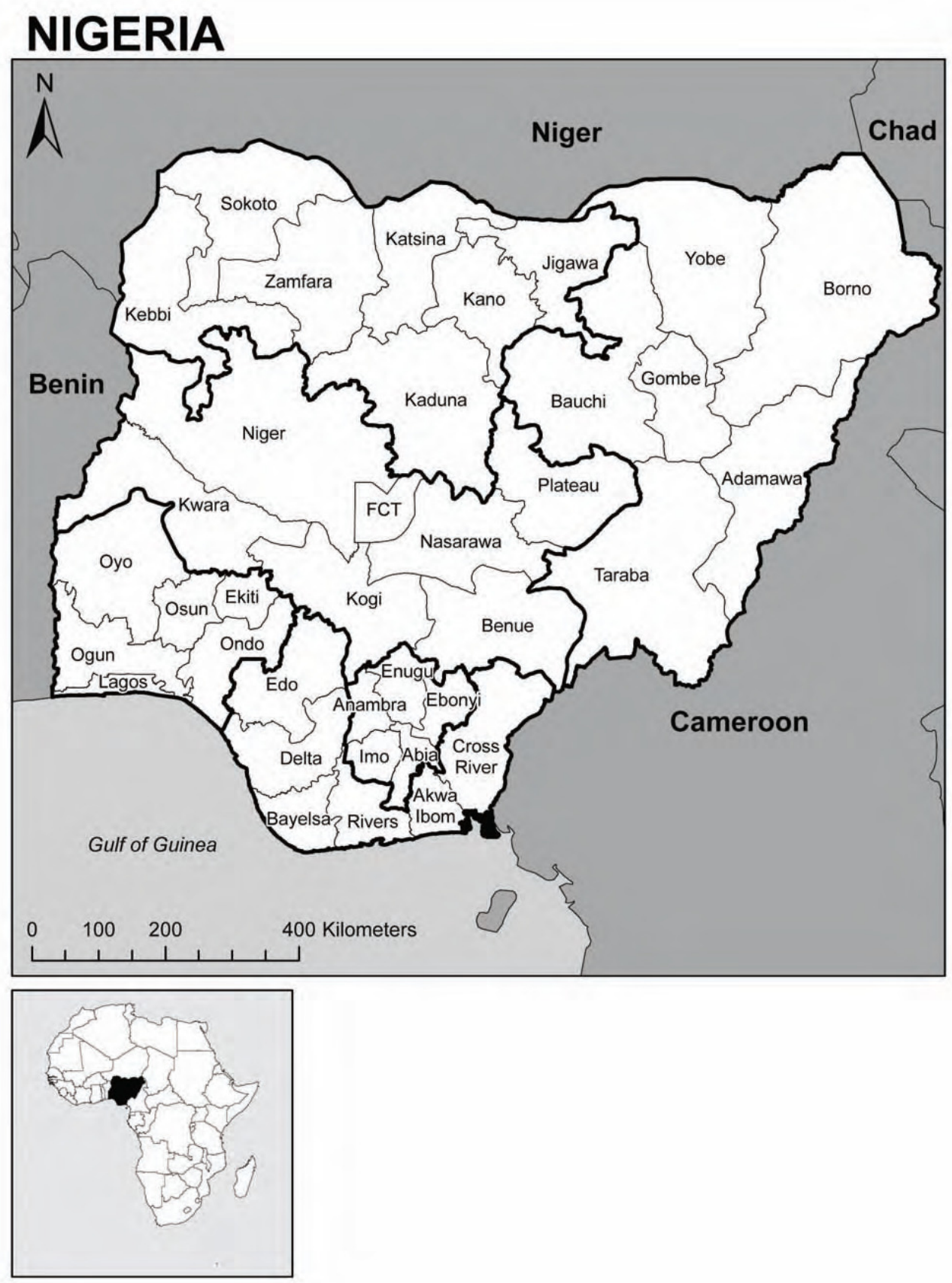

Source: Wikipedia

\subsubsection{Trends in International migration: Nigerian scenario}

In the colonial era, parallel to rural-to-urban migration and migration to and from other African countries, Nigerians have migrated to the UK, principally to follow higher education. A significant proportion of them would stay. After independence in 1960 this largely highly skilled migration to the UK continued, although an increasing proportion of Nigerians migrated to the US for study, business and work.

The 1973 oil crisis and skyrocketing oil prices caused a tremendous (350 percent) increase in oil revenues. The associated economic boom made Nigeria into a major migration destination within Africa. Rising incomes of the urban middle class and rapid industrialisation attracted substantial numbers of West African labour migrants. However, the post 1981 decrease in oil prices would herald a long period of economic downturn alongside sustained political repression and violence. In 1983 and 1985 Nigeria expelled large numbers of West African migrants, including about one million Ghanaians 
(Arthur 1991: 74).

It has therefore been observed that Nigeria has witnessed a 'reverse migration transition, transforming itself from a net immigration to a net emigration country (Black et al. 2004:II). Nigerians have increasingly emigrated to countries such as Ghana, Cameroon, and particularly the wealthy economies of Gabon, Botswana and South Africa (cf. Adepoju 2000). Since 1994, South Africa has developed as a major destination for migrants from various African countries, among which were many Nigerians. In particular, the skilled have found the booming economy of South Africa to be a convenient alternative to Europe, the US and the Gulf States (Adepoju 2004).

Whereas the migration of students, professionals and entrepreneurs to Anglo-Saxon countries has continued, there has been a diversification of Europe-bound migration following the economic decline and increasing political tensions in the 1980s. An increasing number of Nigerians have migrated to countries such as Germany, France, the Netherlands, Belgium as well as the Gulf states. In the 1990s, Spain, Italy and Ireland have emerged as new major destinations of labour migrants from West Africa and Nigeria (cf. Black et al. 2004:9). There has also been an increasing tendency of Nigerian migrants towards permanent settlement. Increasing restrictions and controls on immigration to Europe have not led to a decrease in Nigerian emigration. Rather, migrants are more often un-documented and the itineraries tend to be longer and more perilous. This has made Nigerian migrants more vulnerable to exploitation and marginalisation.

There is circumstantial evidence that these more recent migrants to continental European countries are less skilled on average, and that they more often work in the (formal and, particularly in southern Europe, informal) service, trade and agricultural sectors of the economy. The UK and, in particular the US (through student and professional migration as well as the Green Card lottery), generally continue to attract the relatively more highly skilled workers (cf. Hernandez-Coss et al. 2006). The need to expand the UK National Health Service has for instance created opportunities which poorly paid and unmotivated professional health workers find irresistible. UK universities have also embarked on a recruitment drive of Nigerian students. In Nigeria, countless immigration 'consultants' promise prospective migrants visas and job opportunities. Also the Gulf States primarily have attracted the relatively highly skilled, at least until recently. Education has always been an important cause of Nigerian emigration. Some Nigerians migrate with their children to pursue studies in the US or the UK, to escape the dismal state of the Nigerian educational system.
Labour migration from Nigeria has also become increasingly undertaken by women. For instance, an increasing number of female nurses and doctors have been recruited from Nigeria to work in Saudia Arabia (Adepoju 2000:386).

A significant number of Nigerians apply for refugee status in European countries. In 2004, Nigerians were the fifth largest group of asylum seekers in Europe (Carling 2005). They tend to state ethnic and religious conflict as their reason for asylum. The cases are often denied because it is felt that there are many other states within Nigeria and West Africa for Nigerians to move to if they are faced with persecution at home. Because of its size and its current relative stability, Nigerians have less chance of obtaining asylum status than citizens from other, conflict-ridden, ECOWAS countries. The issue of the trafficking of female Nigerian sex workers to Italy and other European countries has received substantial attention. However, it seems to be important to take into account the complexity of the issue as well as the blurred distinction between forced and voluntary migration. It is also important to make a distinction between trafficking and smuggling.

Most recruiting of future prostitutes takes place in the southern Edo state. The most important destination is Italy, where it is said that as many as 10,000 Nigerian prostitutes are living. Secondary destinations are the Netherlands, Spain and a range of other countries (Carling 2005). When Nigerians began migrating to Italy in the 1980 s as a response to its high demand for low-skilled labour in agriculture and services, these women were only one of many groups that migrated. The first prostitutes tended to work independently. In the early 1990s, immigration restrictions made prospective emigrants increasingly dependent on large loans in order to pay for their journeys. This provided an opportunity for traffickers, who enticed young women to migrate with promises of good jobs, and subsequently coerced them into prostitution to repay their migration debt (Carling 2005).

The initial contact with the traffickers is often made through a relative, friend, or other familiar person, who puts her in contact with a madam who organises and finances the journey. The costs may range from US\$40,000 to US\$100,000. The migrants and the madam conclude a 'pact', which is religiously sealed by a traditional priest, which obliges repayment in exchange for a safe passage to Europe (Carling 2005). 
Figure 2.1 Stock of Nigeria Emigrants in selected developed countries

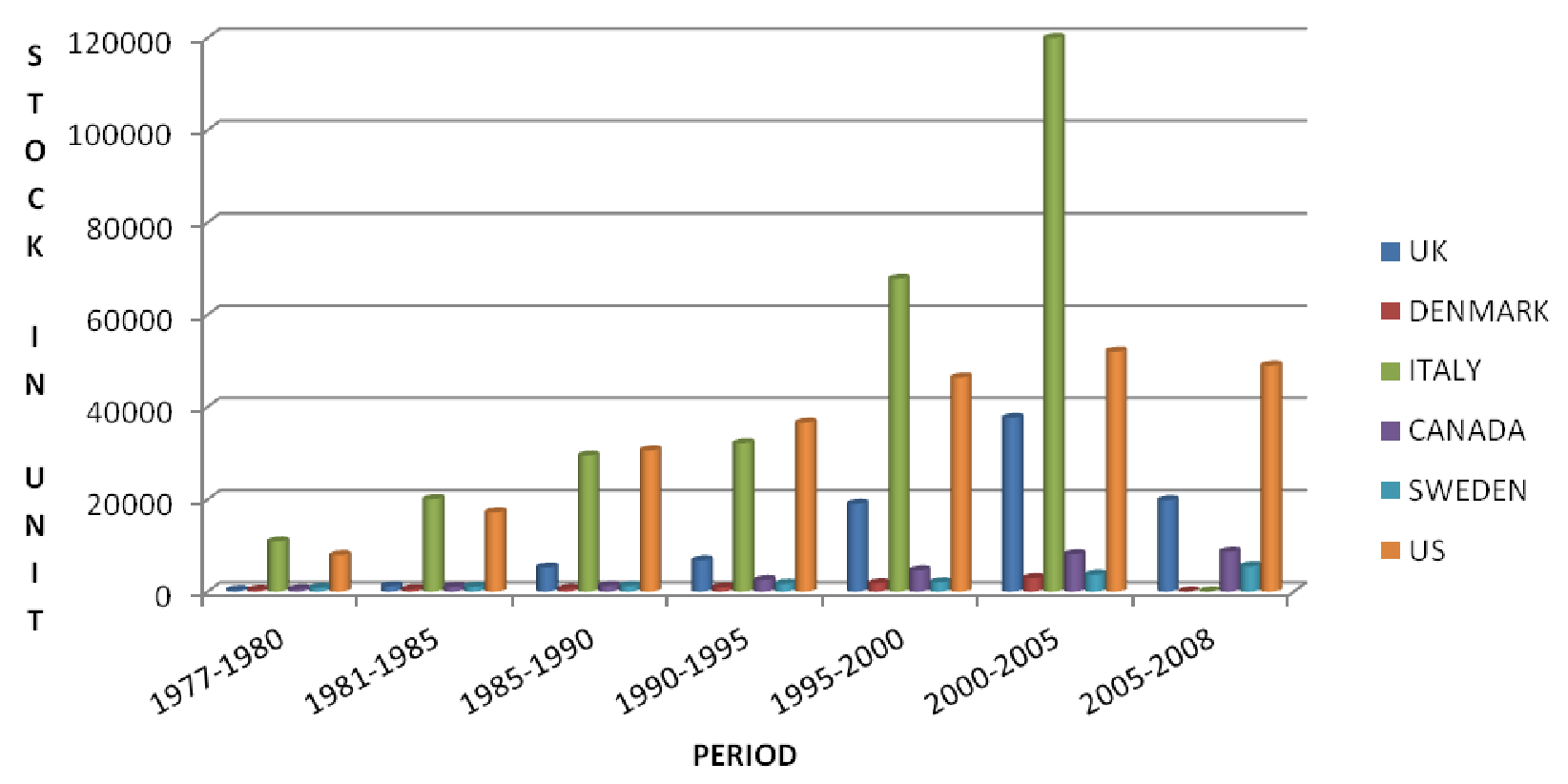

Source: Computed. Underlying data from immigration statistics yearbooks of Canada, \& UK, the US tatistical Abstract and World Development Indicators (2007).

In Europe, the women are under the control of a Nigerian madam, a counterpart of the Nigerian madam. Most women know that they are going to work as prostitutes, but are not necessarily aware of the arduous conditions under which (street) prostitutes have to work as well as the size of the debt. However, this work does offer some 'career' perspectives.

After repaying their debt in one to three years, women are basically free, and it is fairly common for them to become supervisors of other prostitutes and, eventually, a madam themselves. Carling (2005) stressed that this prospect of upward mobility is a strong incentive to comply with the pact, and that this strong element of reciprocity between traffickers and the victims makes it difficult to reduce this form of trafficking. Whereas labour migration and trafficking to Europe used to predominantly use air links, visa requirements and increasing immigration controls at air and seaports seem to have led to an increasing reliance on trans-Saharan, overland routes to the Maghreb countries, and in particular Morocco, from where Nigerians and other subSaharan Africans attempt to cross the Mediterranean sea to southern Europe or the Atlantic ocean to the Canary Islands (de Haas 2006b). According to a recent study, traffickers especially in Kano state successfully exploited the annual pilgrimage to Mecca to traffic children, men and women for different exploitative purposes e.g. prostitution, begging and all forms of domestic work (cf. Ehindero et al. 2006).

\subsection{Stylised facts about international migration in Nigeria}

Figure 2.I shows the stock of Nigerian emigrants in the selected developed countries. Outflow of Nigerians to the countries under study rose systematically between 1971 and 2008. Emigration of Nigerians to Italy appears to be the highest among the countries of immigration. Nigerians in Italy were fewer than 20,000 in 1977-1980, but increased to more than 60,000 in the 1995-2000 period and in the 2000-2005 period; the total of working class Nigerians who were in Italy was computed to be around 1.2 million. In the case of the US, Nigerians were also fewer than 10,000 in the late 1970s but the figure rose to around 37,000 in the 1990-1995 period and to around 50,000 in the 2000-2005 period. Nigerians in the UK were not many compared to the first two destination countries. Nigerians in the UK began to increase meaningfully from 1985-1990 when the figure rose to 6,000. By 19952000 , the figure was close to 20,000 and by 2000 2005 , it was around 40,000. However, in 2005-2008, the outflow of Nigerians to the US and UK fell sharply.

Numbers of Nigerians in Sweden and Denmark were very small, as they were not up to 10,000 in 
any period but they have tended to increase over time. Periodic growth rate of Nigerian migration stock is presented in Figure 2.I. Migration stock grew by less than 10\% in the early 1990s. However, in the 1995-1999 period, Nigerian immigrants into Canada grew by $20 \%$, but the number to the UK and US actually declined. In the 2000-2005 period, the growth rate rose to around $11 \%$ while the growth rate of Nigerians migrating to the US rose to about $5 \%$ and the growth rate of migrants to the UK continued to decline. It turns out that the rate at which Nigerians migrate to Canada was higher than the rate at which they migrate to US or UK, even though the stock of Nigerian in the US at a particular year is substantially greater than that of Canada. Perhaps the reason for this is that Canada appears to be a country that is beginning to attract workers from Africa.

\subsubsection{Characteristics of Nigerian international migrants}

Scattered evidence on the origin of Nigerian immigrants in Europe and the US strongly suggests that the majority originate from the relatively developed and densely populated southern provinces. The lbo from the southeast and the Yoruba from the southwest, and, to a lesser extent the Edo and the Ogoni ethnic groups seem to constitute the majority of Nigerian migrants in the UK (Hernandez-Coss et al. 2006). The majority of Nigerians trafficked to Europe seem to originate from Edo state, and Benin
City in particular. Edo and to a lesser extent the Delta states are known as the main areas of origin of sex workers. The Hausa and other groups from the north seem relatively more oriented to migration to the Gulf states. The predominantly Muslim character of the north as well as the position of the northern city of Kano as a major air hub in the hadj, the Muslim pilgrimage to Mecca, might partially explain this connection.

Reliable or even approximate data on Nigerian migration is generally lacking. Nigerian authorities do not register or estimate emigration, presumably reflecting the low interest in the issue. Receiving country statistics are incomplete, as many countries do not include naturalised and second-generation Nigerians in immigrant statistics and because of the substantial presence of undocumented migrants. Nigeria's PRSP (Poverty Reduction Strategy Paper) estimated that more than 2 million Nigerians (mostly highly educated) have emigrated to Europe and the United States (NNPC 2004), but the empirical basis for this claim remains unclear. A compilation of existing migration statistics shows that more than 300,000 first generation Nigerian migrants were legally living abroad at the beginning of the $21^{\text {st }}$ century (see Table 2). Although the real number is certainly higher if we include second and third generations as well as undocumented migrants, claims that "millions" of Nigerians would live abroad appear to be rather unlikely.

Table I Estimates of Nigerians living outside Africa

\begin{tabular}{|c|c|c|}
\hline Country & Nigerians Abroad & Arrival of asylum seekers (2004) \\
\hline US & 160,000 (2004; country of birth) & NA \\
\hline UK & 88,380 (200I; country of birth) & $\mathrm{I}, 290$ \\
\hline Germany & 16, I83 (2002; nationality) & NA \\
\hline Canada & 10,425 (200I; country of birth) & 589 \\
\hline Ireland & 9, 225 (2002; country of birth) & NA \\
\hline Netherlands & $4,564 \quad$ (2003; country of birth) & NA \\
\hline Italy & 3, 575 (I989; nationality) & NA \\
\hline Austria & 2,913 (200I; country of birth) & $\mathrm{I}, 828$ \\
\hline Greece & $2,021 \quad$ (200I; nationality) & NA \\
\hline Australia & I,783 (200I; country of birth) & NA \\
\hline Belgium & I, 636 (2004; nationality) & NA \\
\hline France & I, 425 (I999; nationality) & $\mathrm{I}, 572$ \\
\hline
\end{tabular}

Source: OECD 2006 and http://www.migrationinformation.org

Black et al. (2004:19) refer to sources suggesting that nearly 15,000 Nigerians enter Europe and North America annually. The UK census in 2001 reported 86,958 Nigerians living in the UK, with about 80 percent living in greater London. However, this does not include undocumented migrants and
UK citizens of Nigerian descent (Hernandez-Coss et al. 2006). There are probably between 200,000 and 300,000 first and second generation Nigerians in the US. This figure perhaps includes up to 21,000 Nigerian doctors, although these figures have been contested. According to the 2000 census, 90,000 of the 
109,000 Nigerian-born immigrants in the US aged 25 or over had tertiary education (Adams 2003).

\subsubsection{Recent trends in international remittances to Africa}

Remittance refers to the portion of migrant income that, in the form of either funds or goods, flows back into the country of origin, primarily to support families back home. The greater share of these largely monetary flows benefits developing countries. In the last few decades the volume of migrants' remittances worldwide has risen steadily (in nominal and relative terms) and currently represents a substantial source of revenue for many poor states.

From the use of banks, credit institutions or money transfer companies like Western Union and MoneyGram to the personal transportation of cash or goods during trips back home, various means exist for transferring remittances to the recipient country. Information concerning cross-border money flows is only available on funds sent through formal channels, as these are the only channels that national banks are able to monitor. Experts estimate that undocumented transactions via informal channels are, in fact, well above officially documented figures. Informal methods of transferring money differ from country to country. In addition to the personal transport of funds, money can be sent through the mail or via a third party.

Before the advent of the financial and economic crises, international remittances flowing into devel- oping countries had been attracting increasing attention because of their rising volume and their impact on the recipient countries (Anyanwu and Erihijakpor, 2009a, 2010). However, the crises have reversed the current trend. It has been estimated that in 2008, international remittances going to developing countries totalled US\$337.8 billion out of the global amount of US\$420.I billion (a $5.3 \%$ fall) while the flows to developing countries fell to US\$317.2 billion (a $6.1 \%$ decline). Though those flows are underreported, a high proportion of the reported flows went to Africa. Between 2000 and 2008, remittances to the continent increased by about 263.7 percent, from US\$II.2 billion to over US\$40.8 billion. Due to the financial and economic crises, the flows to Africa had been projected to fall to nearly US $\$ 38.2$ billion in 2009 , or a $6.3 \%$ decline from its 2008 level (Table 2).

As Table 2 and Figure 2 show, in 2008, East Asia and the Pacific region remained the largest recipient of recorded remittances, followed by South Asia, Latin America and the Caribbean (LAC) region, Europe and Central Asia, Africa (courtesy of favourable North African inflows), and the Middle East, in that order. This reversed the domination by Latin America and the Carribbean (LAC) regions in earlier years. In addition, for the first time in many years, remittance inflows to sub-Saharan Africa dominated those to North Africa (Figure 3). For example, in 2008 , flows to North Africa were US\$19.7 billion as against US\$21.I billion to sub-Saharan Africa.

Table 2 Global flows of international migrant remittances (US\$ million)

\begin{tabular}{|c|c|c|c|c|c|c|c|c|c|c|c|c|c|}
\hline Region & '00 & '0I & '02 & '03 & '04 & '05 & '06 & '07 & '08 & '09e & $\begin{array}{l}\text { \% } \\
\text { Change } \\
\text { ('06- } \\
\text { '07) }\end{array}$ & $\begin{array}{l}\text { \% } \\
\text { Change } \\
\text { ('07- } \\
\text { '08) }\end{array}$ & $\begin{array}{l}\% \\
\text { Change } \\
\text { ('08- } \\
\text { '09) }\end{array}$ \\
\hline $\begin{array}{l}\text { All } \\
\text { developing } \\
\text { contries }\end{array}$ & 82,537 & 93,122 & 112,609 & 140,420 & 164,370 & 198,932 & 235,403 & 289,376 & 337,761 & 317,237 & 22.9 & 16.7 & -6.1 \\
\hline $\begin{array}{l}\text { East Asia } \\
\text { and Pacific }\end{array}$ & 15,675 & 18,757 & 27,468 & 32695 & 40,336 & 50,460 & 57,598 & 71,309 & 86,115 & 84,785 & 23.8 & 20.8 & -1.5 \\
\hline $\begin{array}{l}\text { Europe } \\
\text { and } \\
\text { Central } \\
\text { Asia }\end{array}$ & 12,143 & 11,647 & 12,844 & $|4,4| 8$ & 20,955 & 30,089 & 37,341 & 50,777 & 57,081 & 49,279 & 36.0 & 13.8 & -14.7 \\
\hline $\begin{array}{l}\text { Latin and } \\
\text { Caribbean }\end{array}$ & 19,987 & 24,229 & 27,918 & 36,609 & 43,330 & 50,122 & 59,199 & 63,239 & 64,717 & 58,481 & 6.8 & 2.3 & -9.6 \\
\hline $\begin{array}{l}\text { Middle- } \\
\text { East and } \\
\text { North } \\
\text { Africa }\end{array}$ & 12,898 & 14,653 & 15,211 & 20,361 & 23,034 & 24,958 & 26,112 & 31,364 & 34,696 & 32,212 & 20.1 & 10.6 & -7.2 \\
\hline South Asia & 17,212 & 19,173 & 24,137 & 30,366 & 28,694 & 33,924 & 42,523 & 54,041 & 73,293 & 71,955 & 27.1 & 35.6 & -1.8 \\
\hline $\begin{array}{l}\text { Sub- } \\
\text { Saharan } \\
\text { Africa }\end{array}$ & 4,623 & 4,663 & 5,030 & 5,970 & 8,021 & 9379 & 12,629 & 18,646 & 21,139 & 20,525 & 47.6 & 13.4 & -2.9 \\
\hline $\begin{array}{l}\text { Africa } \\
\text { NB: e = } \\
\text { Estimated }\end{array}$ & $|I, 23|$ & 12,442 & 12,948 & 15,578 & 19,509 & 22,479 & 26,575 & 36,913 & 40,842 & 38,145 & 38.90 & 10.64 & -6.3 \\
\hline
\end{tabular}

Source: Author's Computations from World Bank (2009). 
Figure 2: International Remittances Recipients by Region in 2008 (\%)

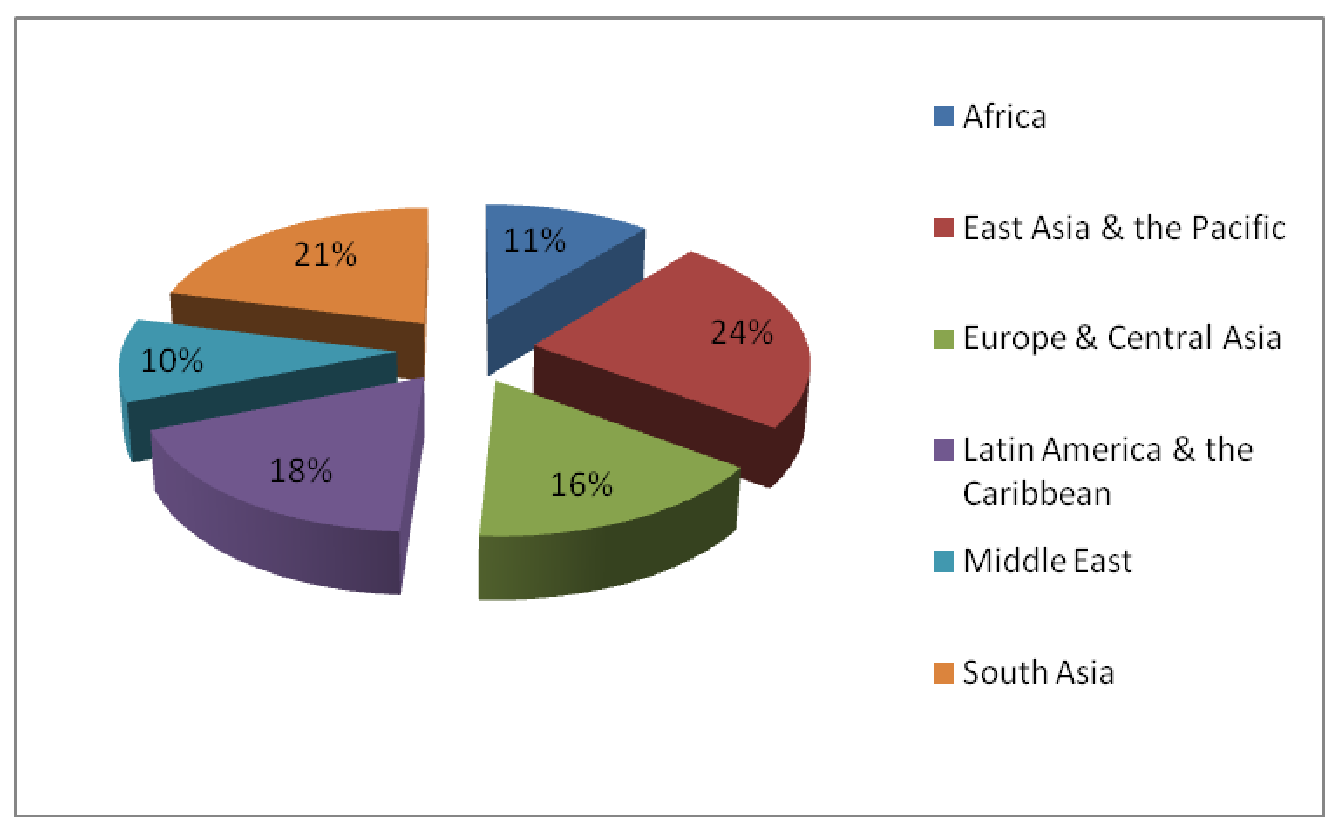

Figure 3: Africa: Regional Share of International Remittances Receipts in 2008 (\%)

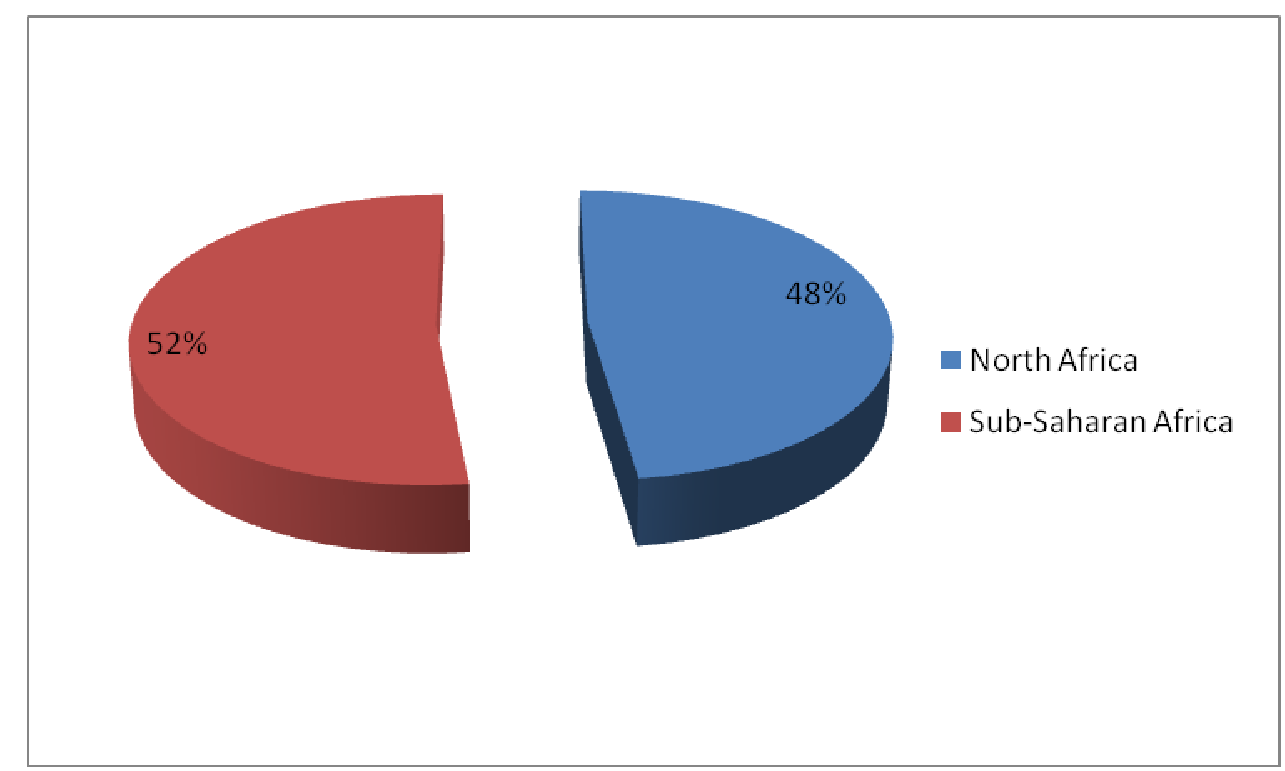

As Figure 4 shows, the top 10 recipients of international remittances in 2008 (in dollar terms) include Nigeria, Egypt, Morocco, Sudan, Algeria, Tunisia, Kenya, Senegal, South Africa and Uganda. As a share of GDP, however, remittances to many of these countries were much smaller in 2008. In contrast, the top recipients in terms of the share of remittances in GDP included smaller economies such as Lesotho and Togo, where remittances exceeded ten percent of the GDP (Figure 5). 
Figure 4: Top Ten International Remittances Recipient Countries in 2008 (US\$ million)

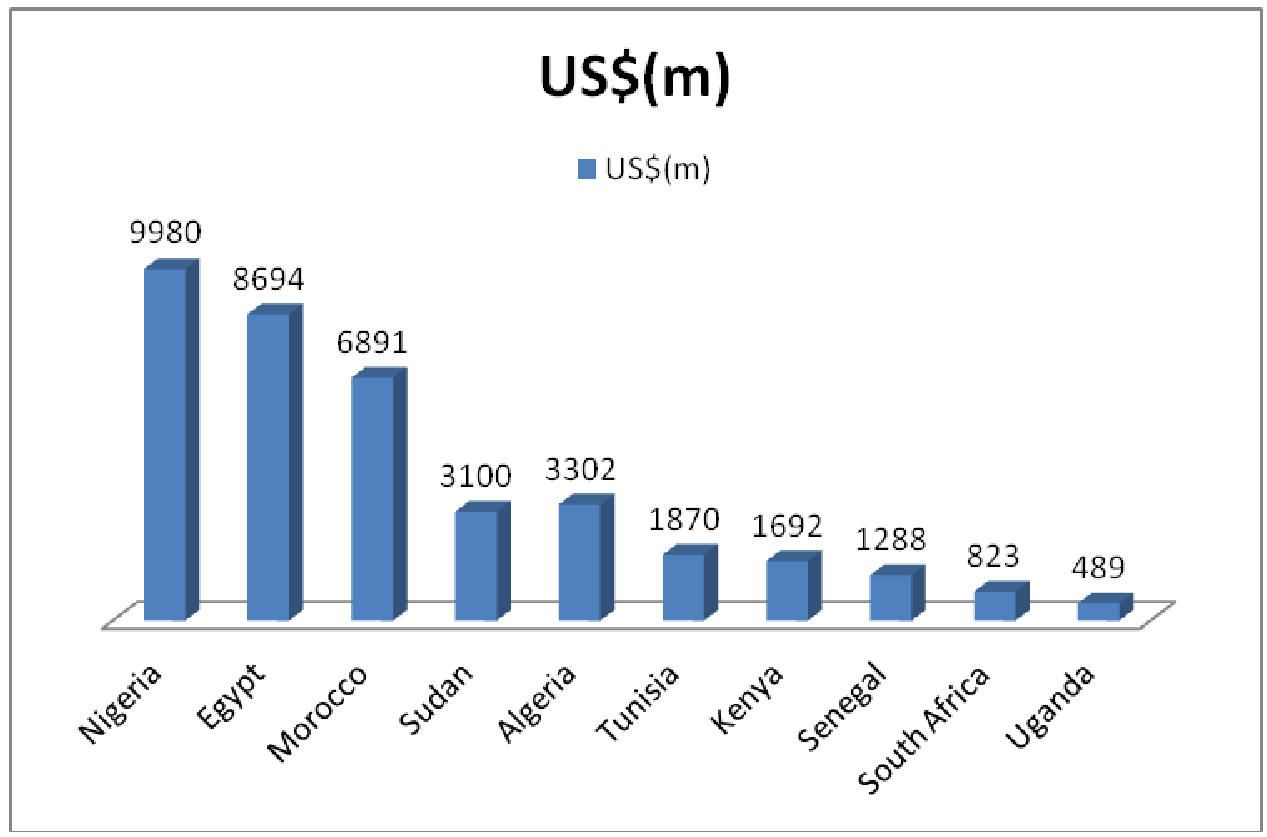

Figure 5: Top Ten International Remittances Recipient Countries in Africa in 2008 (as $\%$ of GDP)

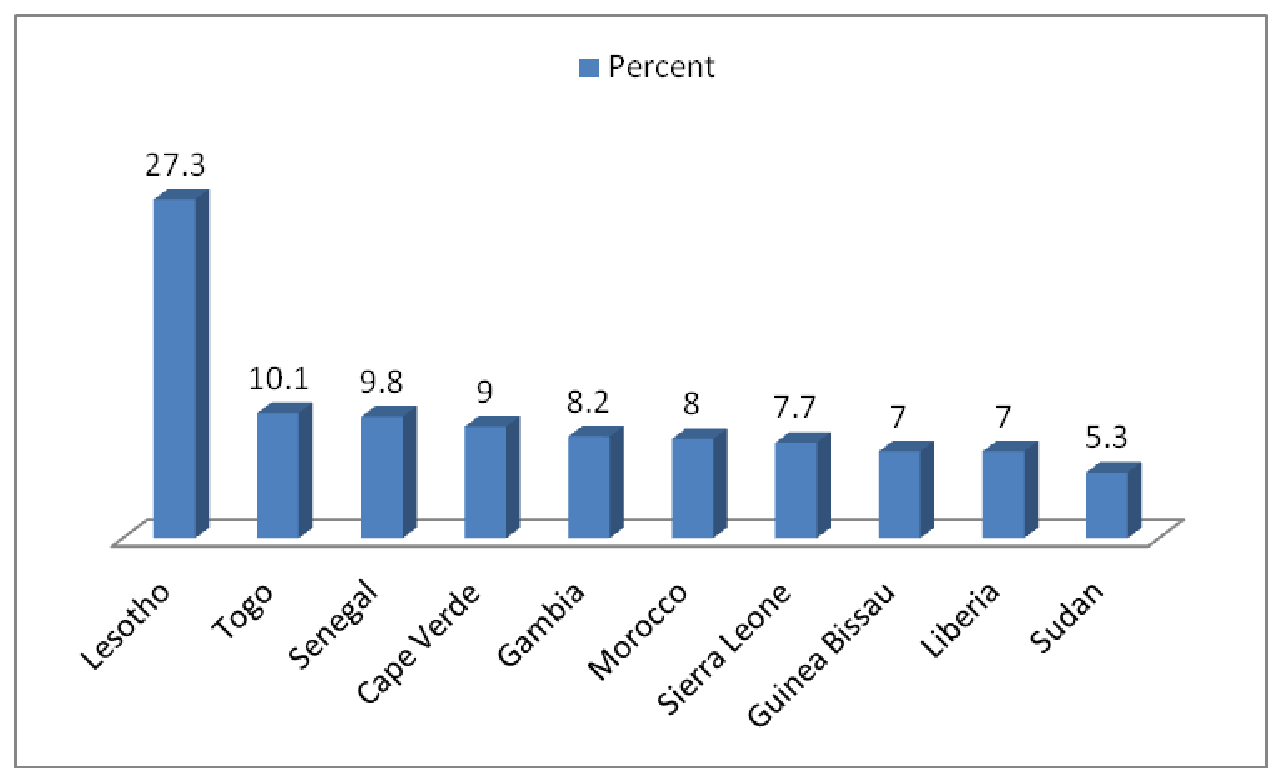

\subsection{Size and Importance of migrant} remittances in developing countries

Remittances have become one of the most significant sources of foreign exchange for African countries. According to the World Bank (2006), offically recorded remittances to developing countries rose to an estimated USD 167 billion in 2005. Due to the flows through informal channels, the true amount could be more than 50 percent higher. According to estimates by the International Fund for Agricultural Development, IFAD, (2007), formal remittance to developing countries amounted to USD300 billion 
in 2006, three times as much as official development assistance in the same year (Schuttler, 2008).

In addition to these remittances sent by individual migrants, money and goods are also transferred to countries of origin on a collective basis (Goldring, 2003). Informal organised groups and registered associations of migrants pool funds on their own initiative or through a plan set up by government or by the group for a great variety of activities. Migrants collectively donate for humanitarian causes or as an investment in public infrastructure. Migrants' organisations' scope, form and size are varied (Moya, 2005) and there are home town associations (HTAs) with members from the same community in the country of origin, religious associations, sport clubs, professional associations, investment groups and political groups. However, only a minority of all migrant organisations aim at promoting development in countries of origin (DeHaas, 2006). Funds sent on a collective basis thus only account for a small fraction of total remittances. Nevertheless, they represent a high quality resource because of their economic, social and political dimension, as well as the transfer of know-how that accompanies them (World Bank, 2002).

\subsection{Social costs and benefits of migration}

Migration in Africa has important effects on social issues that cannot be evaluated purely in economic terms (Ratha et al. 20I I). These costs and benefits include their effects on gender roles and family cohesion.

\subsubsection{Changes in gender role}

Migration shapes values and attitudes toward gender roles within the household (Ghosh, 2009).

When women move, their role as caregivers changes; as a result, men are more likely to engage in traditionally female activities such as caring for children and the elderly (King and Vullnetari, 2006). When men emigrate, women are empowered to take a more prominent part in community decision making, controlling their own income and expanding their role in the domestic sphere (DeshingKar and Grimm, 2005).

Recent migration flows have included a larger number of women who are migrating independently rather than following fathers or husbands (ECA, 2006). Migration provides women with new economic opportunities and sometimes an escape from a failed marriage, particularly in societies in which divorce is not an option. In traditional societies, where divorce is highly uncommon or not possible, migration has been associated with a higher probability of family breakdown. Although protracted separation can take its toll on family cohesion, Lucas (2005) points out that men and women whose marriages were unstable to begin with are more likely to migrate. Gender differences are apparent in other ways. Manuh (200I) finds that Ghanaian men in Canada are more likely than Ghanaian women to return home. For men, the attractiveness lies in the opportunity to go back to a patriarchal society, while women do not relish losing the independence they have experienced in Canada.

Table 2 Remittance flows to selected African countries, 2006-2010. (\$ millions, except where otherwise indicated

\begin{tabular}{|c|c|c|c|c|c|c|c|c|}
\hline & & & & & & & $\begin{array}{l}\text { Growth } \\
\text { (Percent) }\end{array}$ & $\begin{array}{l}\text { Share of } \\
\text { GDP }\end{array}$ \\
\hline Region/country & '06 & '07 & '08 & '09 & $10 \mathrm{e}$ & '08-‘09 & '09-10e & 2009 \\
\hline Nigeria & 5435 & 9221 & 9980 & 9585 & 9975 & -4.0 & 4.1 & 5.5 \\
\hline Sudan & 1179 & 1769 & 3100 & 2993 & 3178 & -3.5 & 6.2 & 5.5 \\
\hline Kenya & 1128 & 1588 & 1692 & 1686 & 1758 & -0.3 & 4.3 & 5.7 \\
\hline Senegal & 925 & 1192 & 1288 & 1191 & 1164 & 7.5 & 2.3 & 9.3 \\
\hline South Africa & 734 & 834 & 823 & 902 & 1008 & 9.7 & 11.8 & 0.3 \\
\hline Uganda & 4 4II & 452 & 724 & 694 & 773 & -4.1 & 11.3 & 4.3 \\
\hline Lesotho & 361 & 451 & 439 & 450 & 525 & 2.6 & 16.7 & 28.5 \\
\hline Mali & 212 & 344 & 431 & 405 & 385 & -6.1 & -4.8 & 4.5 \\
\hline Ethiopia & 172 & 385 & 387 & 353 & 387 & $\begin{array}{l}-8.8 \\
\end{array}$ & 9.7 & 1.2 \\
\hline Togo & 232 & 284 & 337 & 307 & 302 & -9.0 & -1.7 & 10.7 \\
\hline Egypt, Arab Rep & 5330 & 7656 & 8694 & 7150 & 7681 & -17.8 & 7.4 & 3.8 \\
\hline Morocco & 5451 & 6730 & 6895 & 6271 & 6447 & -9.0 & 2.8 & 6.9 \\
\hline Algeria & 1610 & 2120 & 2202 & 2059 & 2031 & -6.5 & -1.3 & 1.5 \\
\hline Tunisia & 1510 & 1716 & 1977 & 1966 & 1960 & -0.5 & -0.3 & 5.0 \\
\hline Djibouti & 28 & 29 & 30 & 28 & 28 & -6.8 & -0.3 & 2.7 \\
\hline Libya & 16 & 16 & 16 & 14 & 16 & -10.1 & 9.3 & 0.0 \\
\hline
\end{tabular}

Source: World Bank (20I I), migration and remittances unit, based on IMF balance of payment statistics. Note: e = estimated. 


\subsubsection{Effects on family cohesion}

Migration may spread attitudes and behaviour from democratic host countries to less democratic spending countries through returning migrants, cross-border communications from Diaspora members, and information networks in migrant-spending communities (Perez-Armendariz and Crow, 2010). Although the decision to migrate may be made in the interest of household welfare, separation from one's immediate family often entails considerable emotional cost and can erode family structures and relationships (D’Emilio, Cordero, Bainvel, Skoog, Comini, Gough, Dias, Saab and Kilbane, 2007). A breakdown of family ties because of emigration can impose significant emotional costs on children (Mckenzie and Rapoport, 2006). To some extent e-mail, text messages, and affordable telephone calls may allow transnational families to thrive even at a distance (UNDP, 2009). Recent evidence from Mozambique suggests that migration may also strengthen social networks by enabling households that receive remittances to participate more actively in their communities (Gallego and Mendola, 2010).)

Table 2 shows selected African countries' remittance data from 2006 to 2010. In 2006, the sum of
USD5.435 billion was remitted from aboard to Nigeria. From 2007 to 2009, the sum of USD9.22I, USD9.980, and USD9.585 respectively were remitted to Nigeria by Nigerian migrants abroad. In 2010 , an estimated USD9.975 was also remitted to Nigeria from abroad. Migration plays a role in microfinance development. Microfinance, the provision of financial services to the poor, has emerged as stimulating sustainable development through local enterprises: micro, small and medium sizes. Migrants' remittances also play a major role in consumption expenditures of households. An asset index composed of land, quality of housing, access to electricity and household amenities was used as a proxy for consumption expenditure (Filmer and Pritchette, 200I). The evidence on whether skilled or unskilled migrants send larger remittances is mixed. Some studies suggest that skilled migrants remit less because they are more likely to settle down in their host countries and eventually bring their families (Niimi and Ozden, 2006; Faini, 2007). Other studies, based on micro-data, find a positive relationship between education and amounts remitted (Clemens, 2009).

Table 3 Formal and informal remittances channels, Nigeria, 2009 (percentage of recipients)

\begin{tabular}{|c|c|c|c|}
\hline & $\begin{array}{l}\text { Remittances } \\
\text { from outside } \\
\text { Africa }\end{array}$ & $\begin{array}{l}\text { Remittances } \\
\text { from within } \\
\text { Africa }\end{array}$ & $\begin{array}{l}\text { Domestic } \\
\text { remittances }\end{array}$ \\
\hline \multicolumn{4}{|l|}{ NIGERIA } \\
\hline Money transfer operator & 57.1 & 35,2 & 6.3 \\
\hline Friend or relative & 12.8 & 15.4 & 21.2 \\
\hline Direct transfer to bank account & 11.8 & 12.1 & 35.0 \\
\hline Bank as paying agent for money transfer operator & 10.5 & 17.6 & 2.6 \\
\hline Brought home by migrant during visit & 5.4 & 13.2 & 27.2 \\
\hline Informal individual agent & 2.5 & 4.4 & 4.1 \\
\hline Postal money order & 0 & 1.1 & 0 \\
\hline Foreign exchange bureau & 0 & $1 . \mathrm{I}$ & 0.1 \\
\hline Credit union & 0 & 0 & 0.2 \\
\hline Travel agency & 0 & 0 & 0.4 \\
\hline Courier, bus or other transport & 0 & 0 & 0.5 \\
\hline Mobile phone or telecom service provider & 0 & 0 & 0.4 \\
\hline Prepaid card or atm card & 0 & 0 & 0.2 \\
\hline Internet money transfer & 0 & 0 & 0.1 \\
\hline Other & 0 & 0 & 1.2 \\
\hline Total & 100.0 & 100.0 & 100.0 \\
\hline
\end{tabular}

Source: Ratha et al. (20I I) based on results of household surveys conducted in Nigeria in 2009

Table 3 shows remittance channels in Nigeria. As a result of the high cost and limited reach of formal channels, as well as the seasonal character of migration, informal channels play a large role in remittance transfers (Ratha et al. 20I I). Remittances by hand during visits to hometowns accounted for $13.2 \%$, within Africa. Remittances from outside Africa through money transfer operators have the highest figure, $57.1 \%$. Informal channels were more prevalent for domestic money transfer, that is, remit- 
tances within Nigeria, which include travel agency: courier or other transport $0.5 \%$; mobile phone $0.4 \%$, internet money transfer $0.1 \%$; prepaid card
$0.2 \%$ and friend or relative $21.2 \%$. In Nigeria, banks account for $37.6 \%$ of the volume of remittances and money transfer companies $6.3 \%$.

Table 4 Use of remittances by recipient households in Nigeria, by source of remittances (percent of total remittances)

Use NIGERIA

\section{Outside Africa Within Africa Domestic}

\begin{tabular}{|c|c|c|c|}
\hline Food & 10.1 & 20.1 & 1.0 \\
\hline Education & 22.1 & 19.6 & 4.5 \\
\hline Health & 5.1 & 12.0 & 10.6 \\
\hline Clothing & - & - & - \\
\hline Rent (house,land) & 4.4 & 4.9 & 0.8 \\
\hline Cars/trucks & 0.0 & 0.0 & 0.5 \\
\hline Marriage/funeral & 0.4 & 1.0 & 0.7 \\
\hline Construction of new house & 5.8 & 0.0 & 0.1 \\
\hline Rebuiding of house & 4.7 & 3.2 & 7.0 \\
\hline Purchase of land & 24.8 & 16.6 & 18.2 \\
\hline Improvement of farm & - & - & - \\
\hline Business & 217 & 20.1 & 11.1 \\
\hline Investment & - & - & - \\
\hline Other & 0.8 & 2.6 & 3.5 \\
\hline
\end{tabular}

Source: Ratha et al. (20I I), calculations based on results of household surveys conducted in Burkina Faso, Kenya, Nigeria, Senegal and Uganda. Note: - means Negligible or missing

Table 4 indicates that remittances are often spent on essential consumption, investment in physical and human capital, and expenditures that improve welfare and productivity, including health, education and information and communication technology. Expenditures on consumption (C) and investment (I) help to accelerate enterprise growth and development, and usually impact positively on national income accounting $(\mathrm{Y}=\mathrm{C}+\mathrm{I})$, and the economic development of Nigeria.

Taylor and Wyatt (1996) argue that the shadow value of remittances for overcoming risk and liquidity constraints is particularly important to households in the low to middle income range, which otherwise tend to be credit constrained. In 1997 , Osili (2004) conducted a survey of 112 Nigerian migrant households in Chicago and a matched sample of $6 \mathrm{I}$ families in Nigeria.

She found that a third of remittances were spent on housing investment the preceding year and that migrants' housing investment was responsive to change in macro-economic conditions such as inflation, the real exchange rate and political stability. In rural Pakistan, international remittances raise the propensity to invest in agricultural land (Adams, 1998). Remittance-receiving households that bene- fited from an exchange rate shock spent more hours in self-employment and were more likely to start relatively capital-intensive entrepreneurial enterprises in the Philippines (Yang, 2008). Some recent studies (for example, Ashraf, Aycinena, Martinez and Yang, 20I0) find that giving migrants more control over the use of remittances can increase savings rates among both migrants and remittance recipients. Abuse of human rights of the Nigerian migrants can exacerbate the inability of migrants to save and remit funds to Nigeria. Also, incessant and prolonged armed conflicts in countries with political instability can reduce the level of remittances, thereby affecting negatively the volume and growth of enterprises in Nigeria.

Remittances may increase expenditure on education by helping finance schooling and reducing the need for child labour. Evidence from household surveys in the table above shows that education was the second highest $(22.1 \%)$ use of remittances from outside Africa. The data shows that remittancerecipients in Nigeria spent more money on food, rather than committing the fund on the improvement of farms.

\subsection{Data and econometric technique}

In this study, our hypothesis is to examine the causal 
relationship between Gross Domestic Product (GDP), Migration and Workers Remittances from abroad and Nigerian Economic growth for the period 2000-200I0.This study makes use of Time Series Data. The sources of the data are annual reports and Statement of Accounts of the Central Bank of Nigeria (CBN), the Federal Bureau of Statistics, (FBS) Nigeria, World Bank, International Monetary Fund (IMF) and International Labour Organization (ILO).

The data involved for this study cover the Gross domestic product (GDP) and Remittances for the period 2000-20I0.

$$
\Delta y_{t}=\beta_{0}+\beta_{1} y_{t-1}+\sum_{j=1}^{n} \alpha_{j} \Delta y_{t-j}+\varepsilon_{t}
$$

Specifically,

$\Delta \ln \mathrm{GDP}_{\mathrm{it}}=\beta_{0},+\beta_{\mathrm{I}} \Delta \mathrm{InREM}_{\mathrm{it}}+\varepsilon_{\mathrm{i}}$

$(\mathrm{I}=\mathrm{I} \ldots \mathrm{N}, \mathrm{t}=\mathrm{I} \ldots \mathrm{Ti})$

Where $\ln =$ is the natural logarithm

$\mathrm{GDP}_{\mathrm{t}}=$ is the gross domestic product (A proxy for growth)

Nigeria

$\mathrm{REM}_{\mathrm{t}}=$ is the inflow of Remittances received in

$$
\begin{aligned}
& \beta_{0},=\text { is the constant term } \\
& \beta_{1}=\text { is the slope } \\
& \varepsilon_{\mathrm{i}}=\text { error term. }
\end{aligned}
$$

For this study, in this empirical analysis, linear regression OLS test would be used to trace the effects of Remittances on GDP. Other economic tests such as stationarity test (using the Augmented Dickey-Fuller (ADF) test), the unit roots tests, co-integration and error correction mechanism were also performed to determine the stationarity of the data and long-run relationship between the variables.
The model

The purpose of the empirical analysis is to determine the causal relationship between Gross Domestic Product (GDP), Remittances and Economic Growth in the Nigerian economy for the period of 2000 2010.

Following John Anyanwu (20I I); Israel Katega (2010) and Nilanjan Banik \& Yoonus (2009) specification as a benchmark, we calculate the relationship between Gross domestic product (GDP), Remittances and economic growth in the Nigerian economy based on the following equation:

\subsection{Interpretation of the results}

We intend to examine if a long-run relationship exists between economic growth and workers' remittances in Nigeria. Thus, in line with the practice in time series econometrics, we move from first testing for the existence of unit roots in the data to testing for the existence of a stable long-run relationship by using cointegration tests. Subsequently, if we find evidence of cointegration, long run estimates can be obtained.

Unit root tests were conducted for all variables in the model and the results are presented in Table 5 below. Both the Augmented Dickey-Fuller (ADF) and Philips Perron (PP) unit root tests were conducted.

\section{Data diagnostics}

As specified earlier, the variables to be employed in this study in line with the model specifications are: GDP (gross domestic product), and FDI (foreign direct investment). A graphical diagnostic representation of the behaviour of the economic variables used in this study (in their log forms) is presented in the following figure: 


\section{REMIT}

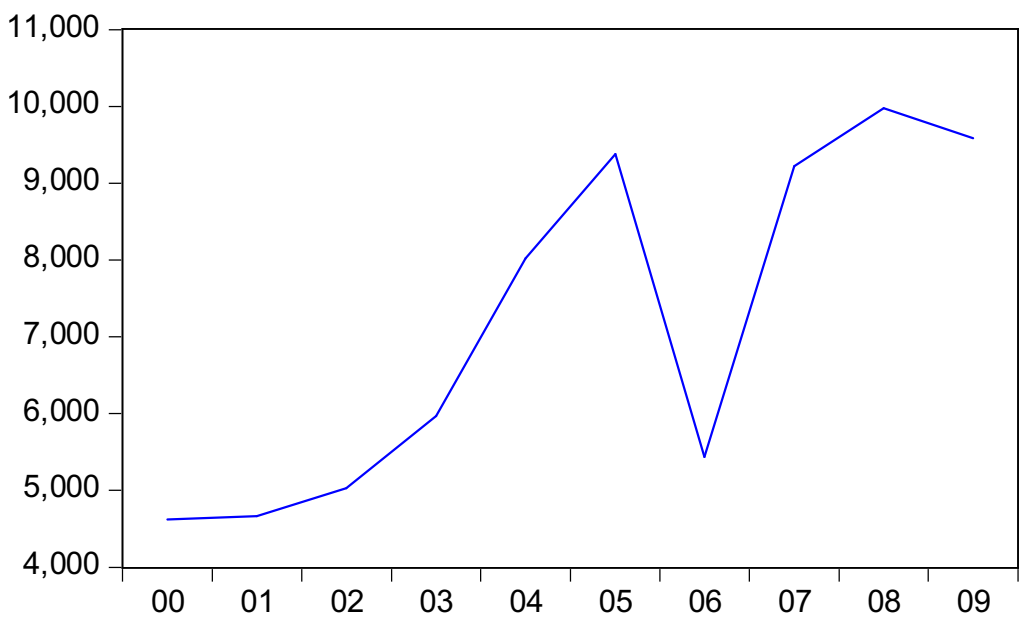

GDP

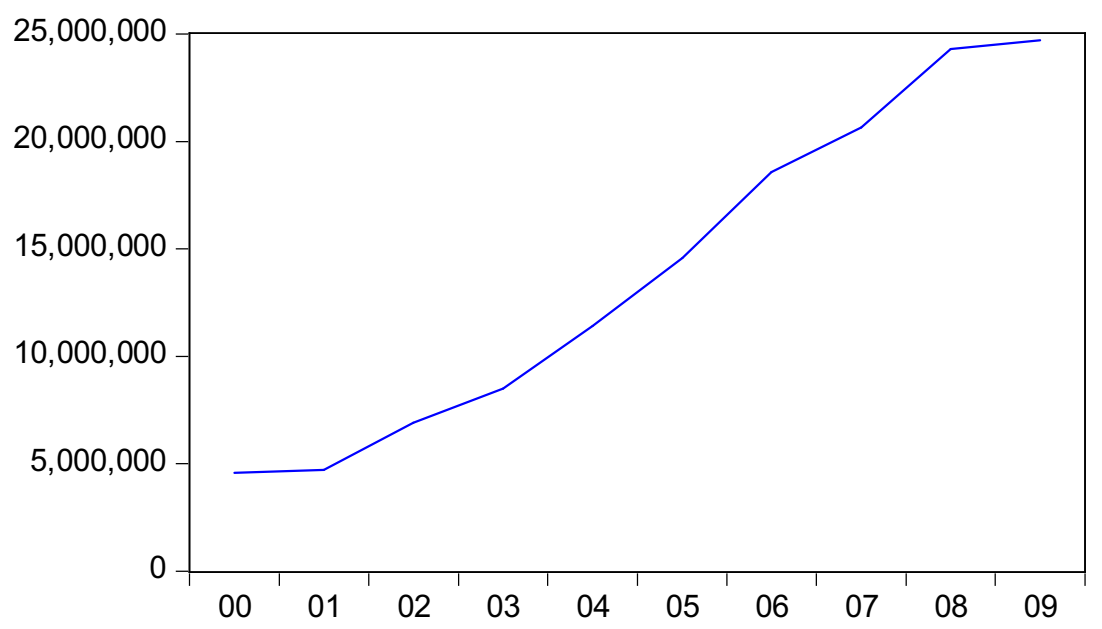

Figure I A graphical representation of the behavior of the economic variables used

Stationarity test

Unit root tests are conducted for the variables using the Augmented Dickey-Fuller test; the results are presented in the table that follows. Note that the MacKinnon (1996) critical values for the Augmented Dickey-Fuller (ADF) test using the Akaike information criterion (AIC) method at $1 \%, 5 \%$ and $10 \%$ sig- nificance level are $-4.803492,-3.403313$ and -2.841819 respectively. Stationarity (unit root) tests conducted for the set of variables enumerated above revealed that the variables are $\mathrm{I}(\mathrm{I})$ and $\mathrm{I}(2)$ variables (integrated of order I and 2). That is, they are not stationary at levels but are all stationary at their various first and second differences.

Table I Stationarity test

\begin{tabular}{llll}
\hline Variables & $\begin{array}{l}\text { Augmented Dickey- } \\
\text { Fuller (ADF) @ Levels } \\
\text { Test statistic }\end{array}$ & Order of integration & Max. no of lags \\
\hline GDP & $-9.903103 * *$ & $\mathrm{I}(\mathrm{I})$ & 9 \\
\hline REMIT & $-3.154489 * *$ & $\mathrm{I}(2)$ & 9 \\
\hline
\end{tabular}

Notes: * indicates significant at *** significant at the $5 \%$ level,

Source: Author's Computation 
3.1.2: Impact on remittances on economic growth: Cointegration result and error correction

Table 2 Cointegration result

\begin{tabular}{|c|c|c|c|c|}
\hline \multicolumn{5}{|c|}{ Trend assumption: Linear deterministic trend } \\
\hline \multicolumn{5}{|c|}{ Lags interval (in first differences): I to I } \\
\hline \multicolumn{5}{|c|}{ Unrestricted Cointegration Rank Test (Trace) } \\
\hline Hypothesised & & Trace & 0.05 & \\
\hline No. of CE(s) & Eigenvalue & Statistic & Critical Value & Prob.*** \\
\hline None * & 0.807113 & 22.17260 & $|5.4947|$ & 0.0042 \\
\hline At most I* & 0.675648 & 9.007401 & $3.84 \mid 466$ & 0.0027 \\
\hline
\end{tabular}

Trace test indicates 2 cointegrating eqn(s) at the 0.05 level

* denotes rejection of the hypothesis at the 0.05 level

Table 3 Error correction result

\begin{tabular}{lllll}
\hline Variable & Coefficient & Std. Error & t-Statistic & Prob. \\
\hline \hline C & 3.789367 & $1.0880 I I$ & 3.482840 & 0.0400 \\
\hline REMIT & $-1.27 \mathrm{E}-06$ & $2.65 \mathrm{E}-05$ & -0.048194 & 0.9646 \\
\hline LREMIT (-I) & $\mathrm{I} .462778$ & 0.223222 & 6.553029 & 0.0072 \\
\hline LREMIT (-2) & -0.024630 & 0.201755 & -0.122076 & 0.9106 \\
\hline ECM (-I) & -0.792937 & 0.185273 & -4.279829 & 0.0234 \\
\hline \hline R-squared & 0.988678 & Mean dependent var & 16.50708 \\
\hline Adjusted R-squared & $0.97358 I$ & S.D. dependent var & 0.482217 \\
\hline S.E. of regression & 0.078379 & Akaike info criterion & -1.985353 \\
\hline Sum squared resid & 0.018430 & Schwarz criterion & -1.935702 \\
\hline Log likelihood & $12.94 I 4 I$ & Hannan-Quinn criter. & -2.320229 \\
\hline F-statistic & 65.49056 & Durbin-Watson stat & 2.051055 \\
\hline Prob (F-statistic) & $0.00299 I$ & & \\
\hline \hline
\end{tabular}

\section{Discussion}

Table 2 above presents the cointegration result for the combined variables. Here, it is observed that the variables in the equation are cointegrated; the existence of this cointegration implies that there is a longrun equilibrium relationship existing between the variables in the equation. This is to say that if a set of variables are cointegrated, the effects of a shock to one variable spread to the others, possibly with time lags, so as to preserve a long-run relationship between the variables. The existence of this longrun relationship is the basis for the short-run disequilibrium adjustment in the model generally known as error correction mechanism (ECM), the result of which is presented in Table 3 above.

It is observable from the results, given the value of the $R^{2}$ (adjusted), that the independent variable in the model significantly explains changes in gross domestic position of Nigeria as about $97 \%$ of changes in the GDP of the country are attributed to the independent variable. The model is significant overall given the probability value of the F-statistic. The Durbin-Watson statistic only corroborates findings that the residual of the model contains insignificant serial correlation.

Coming down to the variables in the model, it is evident that the inclusion of the immediate past period lagged of the dependent variable captures 
part of the changes in GDP accumulation.

The result for Remittances (REMIT) inflows is positive and significant in the first period but for the second, third and fourth period lags that is otherwise. As regards the effect and significance of these variables on Nigeria's Growth incidence (GDP), the result found, in line with the anticipation of this study, that the size of the Gross Domestic Product (GDP) increases with inflow of remittances. Economic theory suggests further that with the inflow of remittances there will be adequate improvement in the recipient standard of living, provision of employment and infrastructure, thus leading to general elevation from poverty, thereby obviating the necessity of de-accumulating the stock of reserves for these purposes. This result also confirms what Soludo (2007) emphasised concerning the positive impact of the variables on reserve accumulation of the country.

\subsection{Conclusion}

The objective of this study was to explore empirically the relationship between remittances (REMIT) and GDP growth in Nigeria. Data were collected from secondary sources and analysed with the aim of achieving the stated objectives. From the findings of the study the following can be inferred: remittances are positively and significantly viable in their contribution to economic growth (proxy by GDP) in origin countries as evident in Nigeria.

Secondly, it is observed that workers' remittances sent to their places of origin in the form of cash and goods play a very important role in subsidising households' livelihoods as they are used to purchase food and consumer goods, paying for medicine and health care, paying for education of the young as well as investing in long term capital projects such as paying for house/land rent, business, rebuilding of houses and the purchase of land.

\subsection{Policy implications}

First, remittances-receiving countries of Africa (especially Nigeria) need to develop a strategy to maximise the benefits of remittances while minimising their negative repercussions. Second, Nigerian governments should design complementary policies to mitigate the adverse income distribution consequences of remittances. Such mitigation policies may range from setting up or improving safety nets, to better labour-market policies and institutions, and to investing in access roads to improve access by the poor to markets.

Third, well-designed additional policy interventions, especially those that improve education and infrastructure and address other "behind the border" investment climate reforms, can mitigate the adverse inequity changes that may result from international migrant transfers (ILO, 2004) Greater access to education will help reduce income inequality in African countries. Thus, bottlenecks in the supply of educated and skilled labour may condemn African countries to high levels of income inequality (World Bank, 2007b).

Fourth, the government and development collaborating agencies such as NGOs should devise ways of assisting migrants in their economic activities and encourage them to continue sending remittances to their places of origin.

Fifth, local government authorities (LGAs) should strive to create enabling environments for the petty businesses in the informal sector to flourish given that they are the businesses that employ most of the migrants' remittances.

Sixth, the LGAs and other development practitioners should educate and encourage urban and rural households that receive international remittances to use them positively and efficiently especially by investing in productive activities such as farming, livestock keeping, bee-keeping, fishing and other viable non-agricultural economic activities such as carpentry.

\section{References}

Adams, Richard H. and John Page. 2005. Do International Migration and Remittances Reduce Poverty in Developing Countries? World Development, Vol. 33, 10: 645-1669.

Adams, Richard H. 2003. Poverty, Inequality and Growth in Selected Middle East and North Africa Countries, 19802000. World Development 31, I2: 2027-2048.

Adams, R.H. 1998. Remittances, Investment and Rural Asset Accumulation in Pakistan. Economic Development and Cultural change 47: I55-I73.

Adams, Richard H. 2006. Remittances, Poverty, and Investment in Guatemala. In Çaglar Özden and Maurice Schiff (eds.) International Migration, Remittances, and the Brain Drain. World Bank, Washington D.C.

Adepoju, A. van Naerssen, T. and A. Zoomers. 2004. Proceedings of the experts meeting. International migration and national development: Viewpoints and policy initiatives in the countries of origin. Working papers Migration and Development series, Report No. 2. Nijmegen.

Arthur, 1991. Remittances, poverty, inequality and welfare. Worldbank internet resources at www.siteresources.worldbank.org/INTRAD...

Ashraf, N.D., Aycinena, C. Martinez and D.Yang. 2010. Remittances and the Problem of Control: A Filed Experiment among Migrants from El Salvador. University Of Michigan, Ann Arbor.

Akinyemi, A., Olaopa. O. and Oloruntimehin, O. 2003. Migration dynamics and changing Rural-urban linkages in Nigeria, at http://iussp/inceton.edu/ download.aspx?submissionld

Black, R., C. Natali and J. Skinner. 2004 and 2005. Migration and Inequality. World Bank, Washington DC. 
Carling.J. 2005. Migrant Remittances and development cooperation. PRIO report Nr. I/2005, International Peace research Institute, Oslo.

Clemens, M. 2009. The Financial Effects Of High-Skilled Emigration: New Data on African Doctors Abroad. Paper Presented at the International Conference on Diaspora for Development, Washington, D.C. July I314.

Central Bank of Nigeria. 2007. Statistical Bulletin. Volume 18, December 2007

2008. Statistical Bulletin.

Deshingkar, P. and S.Grimm. 2005. International Migration and Development: A Global Perspective. Migration Research Series 19, International Organization for Migration, Geneva.

D’ Emilio, A.L., B. Cordero, B. Bainvel, C-Skoog, D. Comini, J. Gough, M. Dias, R. Saab and T. Kilbane. 2007. The Impact of International Migration: Children Left Behind In Selected Countries of Latin America and the Caribbean. Division of Policy and Planning, United Nations Children's Fund (UNICEF) New York.

De Haas, Hein. 2006b. Engaging Diasporas: How Governments and Development Agencies Can Support Diasporas' Involvement in Development of Origin Countries. International Migration Institute, University of Oxford, Oxford.

De Haas, Hein and Roald Plug. 2006. Cherishing the Goose with the Golden Eggs: Trends in Migrant Remittances from Europe to Morocco 1970-2004. International Migration Review 40,3: 603-634.

Economic Commission for Africa, ECA, 2006. International Migration and Development: Implication for Africa. Addis Ababa: Economic Commission for Africa.

Ehindero et al. 2006. Migration and development in Nigeria, at www.academicjournals.org/.../Ojukwu.pdf

Filmer, D. and L. Pritchett. 200 I. Estimating Wealth Effects without Expenditure Data or Tears: An Application to Educational Enrollments in States of India. Demography 38(I): II5-I32.

Gallego, J.M and M. Mendola. 2010. Labor Migration and Social Networks Participation: Evidence from Southern Mozambique. Working Paper 183. Department of Economics, University Of Milano-Bicocca.

Ghosh, J. 2009. Migration and Gender Empowerment: Recent Trends and Emerging Issues. Human Development Research Paper 4, Limited Nations Development Programme, New York.

Goldring, 2003. Rethinking Remittances. CERLAC Working Paper Series. Department of Sociology, York University

Hernandez-Coss, R. 2006. A proposed framework to analyze informal funds transfer systems in Munzele, $\mathrm{S}$ and D. Ratha, Remittances, Development impact and Future prospects. The World Bank, Washington DC.

IFAD. 2007. Sending Money Home: Worldwide Remittance Flows to Developing Countries. International Fund for Agricultural Development, Rome.
Israel B. Katega 20I0. Rural-Urban Migration, Remittances and Rural Poverty Alleviation in Tanzania: A case Study of Migrants from Kondoa District

International Monetary Funk, IMF 2005. Balance of Payments Statistics Yearbook 2005. Washington: IMF.

Jandl, M. 2003. Moldova Seeks Stability Amid Mass Emigration. Country Profile. Washington D.C.: Migration Policy Insitute.

John Anyanwu. 20I I. International remittances and income inequality in Africa. Working paper series 135, Ideas Repec.

King, R. and J. Vullnetari. 2006. Orphan Pensioners and Migrating Grandparents: The Impact of Mass Migration on Older People in Rural Albania. Ageing \& Society 26, 5 : 783-8I6.

Lucas, R.E.B. 2005. International migration and Economic development: lessons from low-income countries, executive summary, EGDI.

McKenzie, David, J. 2006. Beyond Remittances: The Effects of Migration on Mexican Households. In Çaglar Özden and Maurice Schiff (eds.) International Migration, Remittances, and the Brain Drain. World Bank, Washington D.C.

Organisation for Economic Co-operation and Development, OECD (Hg.) 2005. Migration, Remittances and Development. Paris: OECD.

Perez, A and David Crow. 20I0. Linkages between migration and Democratization: A case study on Mexico. www.mpa.science.po.fr/fileadmin/fi...

Ratha, D. 2003. Workers Remittances: An Important and Stable Source of External Development Finance. Global Development Finance 2003. Washington: World Bank.

Small, C. A. Dixon, D. L. 2004. Tonga: Migration and the Homeland. Country Profile. Washington, D.C.: Migration Policy Insitute.

Straubhaar, T. and Vadean, F. 2006. International Migrant Remittances and their Role in Development. International Migration Outlook: SOPEMI. 2006. Paris: OECD.

Todaro, M.P. 1992. Economics for a developing world: An introduction to principles, problems and policies for development. Third Edition, Pearson Education Limited, Edinburgh, Harlow, Essex, England.

United Nations Development Programme (UNDP). 2009. Nigeria: Human Development Report. NewYork: Oxford University Press.

World Bank. 20I I. "The Migration and Remittances Factbook” World Bank, Washington, DC.

World Bank 2007. "World Development Report”, World Bank, Washington, DC.

World Bank 2005. Global Economic Prospects 2006. Economic Implications of Remittances and Migration. Washington: World Bank.

World Bank. 2006. Global Economic Prospects 2006: Economic Implications of Remittances and Migration. World Bank, Washington D.C.

World Bank 2002. Global Poverty Monitoring database. World Bank, Washington, DC. 